\title{
Pre-Service Teachers' Perceptions on the Role of English Teachers
}

\section{Percepciones de los docentes de pregrado alrededor del rol de los docentes de inglés}

\section{Angélica María Carvajal \\ Universidad Santo Tomás \\ angelica.carvajal@ustadistancia.edu.co \\ Yolanda Duarte Medina \\ Universidad Santo Tomás \\ yolandaduarte@ustadistancia.edu.co}

Received: November 7, 2019

Accepted: December 2, 2019

How to cite this article (APA, 6th ed.):

Carvajal, A. M., \& Duarte, Y. (2019). Pre-service teachers' perceptions on the role of English teachers. ENLETAWA Journal, 12(2), 58-75.

\begin{abstract}
This small-scale research project was carried out with 15 pre-service teachers enrolled in a B.A. English as a Foreign Language program at a private university with a distance learning modality. The goal of this study was to enable pre-service teachers to express what they thought their role as English teachers should be. The researchers chose narrative inquiry as a way to hear the students' voices and take them into account in order to promote positive changes in their teaching practice. Different data collection instruments were implemented, such as oral narratives from an unstructured interview, written narratives from tutors' reflections in a journal, and a questionnaire to characterize the participants. The findings showed that the pre- service teachers characterized the role of the English teacher as being committed and engaged in the learning process. They also displayed an empathetic attitude toward teaching in the English classroom. Additionally, they highlighted innovativeness and open-mindedness as crucial traits for creating a positive environment in the classroom and activating the affective filter.
\end{abstract}

Key words: English teacher's role, distance education, pedagogical practices, perceptions. 


\section{Resumen}

Esta investigación a pequeña escala se llevó a cabo con un grupo de 15 maestros en formación pertenecientes a la Licenciatura en Lengua Extranjera, Inglés, en una universidad privada de Educación a Distancia, cuyo objetivo era permitir que los estudiantes expresaran sus percepciones sobre los roles de un docente de Inglés. Para recolectar la información los investigadores eligieron instrumentos como narraciones orales obtenidas de entrevistas no estructuradas, narraciones escritas provenientes de las reflexiones de los tutores compiladas en un diario de campo y finalmente, un cuestionario para caracterizar a los participantes. Los resultados muestran que los maestros en formación describen el rol del tutor de inglés como una persona dedicada y comprometida con el proceso de aprendizaje. También hacen evidente que una actitud comprensiva, así como ser innovador y de mente abierta, son factores que promueven un ambiente agradable para el aprendizaje y que contribuyen a reducir el filtro afectivo.

Palabras clave: educación a distancia, el rol del tutor del inglés, percepciones, prácticas pedagógicas. 


\section{Introduction}

This small-scale project is a narrative study aimed to describe preservice teachers' perceptions around the role of being an English teacher. The target population was a group of 12 pre-service teachers enrolled in a B.A. program in English as a Foreign Language at a private university with a distance learning modality. We selected the participants randomly in order to get data from students enrolled in different semesters and who varied in their English language proficiency (A1 to B2 according to the Common European Framework of References for Languages).

The idea for this study came about the need to listen to the pre-service teachers' voices on the role teachers play in educational settings. Furthermore, we wanted to make their perceptions and insights visible on what teaching a foreign language implies, especially because they were mainly learning through a distance education modality.

To gather data, different instruments were considered. First, oral narratives through an unstructured interview were collected. These spoken narratives helped us understand the preservice teachers' perceptions about the characteristics of being an English teacher and how they can influence their performance as future in-service teachers. Second, we utilized written narratives from tutors' reflections in a journal. Finally, we used a questionnaire to characterize the participants.

\section{Context and Setting}

The study was done with 15 university students, made up of 8 women and 7 men, whose ages ranged from 19 to 25 years old. They were enrolled in different semesters. Therefore, their English language proficiency level varied from A1 (Beginners) to B2 (Advanced) based on the CEFR guidelines. The students come from different towns and villages from Boyacá and Cundinamarca, such as Chiquinquirá, Saboya, Ubaté, and Simijacá.

The students live in strata 2 and 3 according to the socio-economic stratification system in Colombia. They are currently enrolled in the Bachelor in English as a Foreign Language program. The modality of the program is distance learning, which means they study online using a virtual platform during the week. On Saturday, they visit campus for face to face tutorial sessions. Three or the 15 students graduated from a teacher training school (Escuela Normal), while the others come from public and private institutions. 
The students were chosen randomly using probability sampling since we wanted to explain, predict, and generalize the results for the group of pre-service teachers.

\section{Research Statement}

This narrative study aims at researching the students' stories and life experiences. As the researchers, we questioned what pre-service teachers' perceptions were on the role of being English teachers in a distance learning program. Then, we chose to listen to their voices as they were the main subjects of the learning process. Trahar (2011) stated that narratives are more than telling and analyzing stories. Thus, this study focused on the pre-service teachers' stories, as well as restoring and position the role of the English teacher based on distance learning.

The objective of this study was to portray the participants' voices and give visibility to their perceptions and insights about teaching a foreign language. The relevance of the story or experiences of the teacher(s) and learner(s) constitutes the voices of the project. As Casey (1995, as cited in Barkhuizen, 2014) stated, "Narrative inquiry expands and empowers the voices and stories or marginalized subjects told in research reports" (p. 3).
As part of the investigation component of the program, macro and subprojects have been proposed by the VUAD (Vicerrectoría General Universidad Abierta y a Distancia) at USTA (Universidad Santo Tomás) as a new research methodology. In this sense, this study contributes to the LLEI (Licenciatura en Lengua Extranjera, Inglés [Bachelor of Foreign Languages, English]) voices' subproject and its realities in terms of: (a) amplifying unheard or unknown teachers and learners' voices and (b) the significance of doing narrative research in distance education contexts considering Chiquinquirá's regional realities. The VUAD subproject is understood as a research unit in which professors work with students in developing the investigative competence. In other words, teachers accompany the research process with students rather than provide orders on how to research. Bonilla et al. (20179 explained that,

These competences and this methodology has been implemented and the research group has boosted the teamwork with all the Professors in the program (both national and regional) to make the project feasible and coherent, and to have everybody participating in the design of protocols and strategies, 
besides working on presenting students with the new approach to research at the Licenciatura en Lengua Extranjera Inglés. (p. 2)

\section{Research question}

How do pre-service teachers perceive the role of being English teachers while studying a Bachelor of Art in English as a Foreign Language with a distance learning modality?

\section{Research sub-questions:}

1. What characterizes the role of being an English teacher in a distance university program?

2. How are pre-service teachers influenced by these perceptions given that they will be future in-service teachers?

\section{Research objective}

To describe pre-service teachers' perceptions around the role of being English teachers in the Bachelor of Arts in English as a Foreign Language at a distance learning university.

\section{Theoretical Background}

The focus of this study is to describe the pre-service teachers' perceptions about the role of English teachers in a distance

learning program. Therefore, the main constructs are as follows: perceptions, English teachers' role, Bachelor of Arts in English as a Foreign Language in a distance learning program, and pedagogical practices.

Perceptions. Given that this study describes the pre-service teachers' perceptions, it is necessary to recognize their life experiences. According to Polkinghorne (1995), "Stories express a kind of knowledge that uniquely describes human experience in which actions and happenings contribute positively and negatively to attaining goals and fulfilling purposes" (p. 8). Because of this, listening to the participants' voices allowed us, the researchers, to collect data and understand the characteristics of being an English teacher.

Bearing in mind that we need to listen to the experiences that shaped the students' lives, it is crucial to represent their thoughts and ideas. As Pavlenko \& Norton (2007) indicated "If we do not acknowledge the imagined communities of the learners, we may exacerbate their non-participation and impact their learning trajectories in negative ways" (p. 598). So that, there is an urgent call to give voice to pre-service teacher in a way that our re-storying could 
help them in shaping their further role as inservice teachers.

\section{Gathering perceptions is a} qualitative process of data collection focused on personal experiences, feelings, and attitudes, as well as the importance of actions and processes (Walker \& Pennington, 2010). In this sense, we decided to use different data collection instruments to amplify the participants' voices. As a further aspect of this study, it was necessary for the tutors to provide constructive and supportive feedback based on these perceptions. At the university's CAU (Centro de Atención Universitaria [Center for University Attention]), rapport building between tutors and students is encouraged. Rapport is a friendly way of treating fellow peers, teachers, tutors, etc. in the classroom. Harmer (2007) stated that rapport building meant establishing a level of respect, humor, and trust. At the CAU, tutors and pre-service teachers are given information of who the other is. Additionally, Whatsapp, Facebook, and email communication is used to establish rapport between students and tutors.

\section{The Role of the English Teacher.}

The role of the English teacher for this study is understood as being made up of a group of characteristics that each tutor must possess in order to guided pre-service teachers in the B.A. program. Dörney and Murphey (2003) mentioned that it was relevant to foster good relationships with our students, so that everyone can work cooperatively and with harmonious creativity and a friendly spirit. Teachers must also be good leaders, who promote autonomy and democratic practices. Furthermore, teachers should also be motivators, which allow students to become active participants in the learning process. If teachers can motivate their students and become mentors and guides, then the classroom becomes less authoritarian and teacher-centered (Rogers, 2013).

The role of USTA's tutors are framed under Harmer's (2015) guidelines. For example, each tutoring sessions is tailored to the students' needs. Tutors must also make a good impression and create a friendly atmosphere. A student's first perception of the tutor is of vital importance in this program. In addition to creating a first impression, tutors also have to be well prepared. They must teach what they have planned, however, be alert to students' reactions and respond accordingly. For example, tutors may have to move on to another subject or expand on a question depending on the students' needs. 
To summarize, the role of the English teacher in this program includes the following:

$\checkmark$ Build rapport with students

$\checkmark$ Provide explanations

$\checkmark$ Be flexible based on students' needs

$\checkmark$ Receive and provide feedback on students' comments

$\checkmark$ Answer students' questions and listen to suggestions

Distance Education. The students who participated in this study are enrolled in a distance learning B.A program. They chose this kind of modality mainly because they work or live far away from the university. Therefore, they cannot attend class during the weekday. According to the Encyclopedia Britannica, distance learning is also known as "distance education, elearning, and online learning" (n.p.). It is defined as "a form of education in which the main elements include physical separation of teachers and students during instruction and the use of various technologies to facilitate student-teacher and student-student communication" (n.p.). Given that teachers and students are physically separated, learning platforms are useful ways to engage students' learning and present the material. At the university, teachers have to collaborate technology and in class time, such as using video conferencing and face-to-face tutoring sessions.

The distance education courses offered in the B.A. program are designed with social constructivist theories in mind, such as incorporating teaching strategies that require learners to communicate, collaborate, explore, and reflect (Lebow, 1993, as cited in Zhang \& Kenny, 2010). Students are encouraged to become autonomous learners. Through collaborative work, they should also enhance their social interaction and problem-solving skills. In addition, students should be able to make alliances and take on an active role when making decisions in groups.

Simonson (2011) identified four main characteristics in distance education. The first one is that institutions, such as universities, colleges and schools, which are trained in this modality and have the necessary technology (learning platforms), are mainly the ones in charge of delivering this kind of education. Second, it is flexible in time and place meaning that students are not required to be physically present. There are no fixed class schedules, and the study material will be available on the platform at any time of the day. Third, synchronous and asynchronous tools, for instance, chats, forums, videoconference, and e-mail, 
promote interaction among teachers and students. Finally, distance education builds a learning community that involves teachers, students and pedagogical resources.

Without a doubt, distance learning can be advantageous for university students. For instance, students with unique circumstances can conveniently access education from their homes. Vissier et al. (2014) provided a clear explanation on how distance learning can develop by means of sharing and developing knowledge across time and space. Therefore, distance learning can support a new economy of knowledge acquisition, production, and exchange.

\section{Teaching Practices. Teaching} practices are an essential component of any B.A. program. Marais and Meier (as cited in Kiggundu and Nayimuli, 2009) mentioned that teaching practices were a challenging but essential part of teacher trained that allowed pre-service teachers to gain experience before facing the realities of the teaching profession. In the TEFL (Teaching English as a Foreign Language) context, the teaching practicum is an opportunity to expose one's self to the real world of teaching, as well as to variety of students, ages, and backgrounds. Preservice teachers can gain knowledge on the complexity of classroom situations. All of the above can enhance pre-service teachers' motivations, attitudes, and engagement towards the teaching profession (Fajardo \& Miranda, 2015).

During the 9th and 10th semester of the B.A. English as a Foreign Language program, students have to enroll in the practicum and teach English at a school. One of the main goals of the practicum is to provide the conditions for students to develop their teaching skills and reflect on their own practices. This reflection process, also known as "reflection in action" (Harmer, 2015) helps students take action based on the different classroom situations they may encounter while teaching. Camacho and Cote (2012, as cited in Castañeda \& Aguirre, 2018) stated that preservice teachers are engaged in constant reflection, and they make decisions based on their own personal ideas.

The importance of the practicum lies in what Smith and Lev-Ari (as cited in Yan \& He, 2010) defined as Practical Theory. Practical theory is the idea that a bridge exists between theory and practice when learning and teaching a language. Moreover, the context will also be important in developing a personalized student-teacher teaching competence. It is evident that the practicum strongly 
influences pre-service teachers' perceptions about the roles they believe teachers to possess. The practicum also helps pre-service teachers develop professional values and attitudes, as well as gain control of knowledge and practice (Eraut, 1988, as cited in Yan \& He, 2010).

The teaching practice is a process that enables and enriches pre-service teachers' knowledge, skills, and experiences. More importantly, it is an opportunity to continue professional growth (Richards, 2002, as cited in Morales, 2016). It is an essential process, and with the help of experts, pre-service teachers can make the best decisions based on their students' needs.

\section{Research Design}

We chose to use narrative inquiry for this study as it was the most adequate approach to portray the pre-service teachers' insights on the role of the English teacher. Narrative inquiry is defined as "the best for capturing the detailed stories or life experiences of a single life or the lives of a small number of individuals. Narrative inquiry is stories lived and told" (Clandinin \& Connelly, 2000, p. 20).

One relevant aspect in using narrative inquiry is that it allows the students' voices to be heard and amplified based on their points of views and not the researchers'. Casey (1995, as cited in Barkhuizen, 2014) stated that "Narrative inquiry expands and empowers the voices and stories or marginalized subjects told in research reports" (p. 3). As mentioned previously, one of the goals of this project was to listen to the pre-service teachers' voices. The participants must engage in the practicum and receive training on how to be English teachers. Nevertheless, they must be the agents of change within their future institutions, and they must expand their voice of knowledge in practice to transform their contexts for the better.

The B.A in English as a Foreign Language is always seeking to support it students' research competences and command of the language, as well as instilling a solid humanistic foundation in education. Because of the latter, we chose to use narrative inquiry since Polkinghorne (1995) claimed that "Stories express a kind of knowledge that uniquely describes human experience in which actions and happenings contribute positively and negatively to attaining goals and fulfilling purposes" (p. 8).

Bearing in mind that we need to listen to the experiences that have helped shape our students' lives, we decided to represent the pre-service teachers' 
thoughts. Pavlenko (2008) indicated that "Narratives are not solely individual productions but they are shaped by social, cultural, and historical contexts as well as by the relationship between the narrator and the interlocutor". Narrative inquiry must be an educative process that provides a space for participants to tell and retell lived experiences, as well as their perceptions and identities as future English teachers. To analyze these stories, we used the narrative cycle. Narrative cycle has multiple directions (Clandinin \& Connelly, 2000) in terms of past experiences and the places where the pre-service teachers have lived them in their educational process during the B.A. program.

For this study, we chose different data collection instruments in order to describe and analyze the pre-service teachers' perceptions around the role of English teachers in a distance learning B.A. program. First, we analyzed oral narratives from unstructured interviews in which we had asked the pre-service teachers to share their vision about the characteristics of an English teacher. Next, we looked at the written narratives based on the tutor's reflections at the CAU, which were obtained through a journal. Finally, we gave the participants a questionnaire to characterize them.

\section{Data Collection and Analysis}

To analyze the data, we followed the following steps of the narrative thematic analysis:

1. Become familiar with the data: This phase involved reading and re-reading the data to become immersed with its content.

2. Coding: This phase involved looking at the data and labeling codes that identified the information relevant to answering the research question.

3. Searching for themes: In this phase, we identified broader patterns of meaning, which we labeled as potential themes.

4. Reviewing themes: This phase involved refining, combining, and discarding themes in regard to the research question.

5. Defining and naming themes: This phased working out the scope and focus of each theme, as well deciding on the final name.

6. Writing up: In this final phase, we contextualized the themes with the literature, and we added relevant evidence to support the section.

After the analysis process, we identified four main categories based on the themes we found (see Table 1). 
Table 1

Four Main Categories

\section{RESEARCH QUESTION}

How do pre-service teachers perceive the role of being English teachers while studying a Bachelor of Art in English as a Foreign Language with a distance learning modality?

\begin{tabular}{|l|l|}
\hline SUB QUESTIONS & CATEGORIES \\
\hline $\begin{array}{l}\text { Subquestion 1. What characterizes the role of being } \\
\text { an English teacher in a distance university program? }\end{array}$ & $\begin{array}{l}\text { Teaching with commitment and } \\
\text { engaging in the learning process }\end{array}$ \\
\hline $\begin{array}{l}\text { Subquestion 2. How are pre-service teachers } \\
\text { influenced by these perceptions given that they will attitude in English } \\
\text { be future in-service teachers? }\end{array}$ & Being innovative and open minded \\
& \\
\hline
\end{tabular}

\section{Teaching with commitment and} engaging in the learning process. The data revealed one essential aspect on how teaching reflected teachers' engagement and commitment during the tutoring sessions. As teachers, we can show our commitment when we know what we are doing and have given our lessons some forethought. To engage students, it is necessary to keep a brisk pace so that they stay on task and demonstrate a positive attitude (Lauría de Gentile, 2009). Additionally, a teacher's commitment and engagement can spark students' enthusiastic attitudes. The excerpts below come from the unstructured interview with the pre-service teachers and support the category. 
A good teacher has to have a posture, teaching his students with commitment and engage them into learning process. [sic] (Pre-service teacher's interview, Transcript 8)

Teachers in Colombia have a big responsibility that is to change the chip about ELT, we must help our students to like English so that we must be creative. [sic] (Pre-service teacher's interview, Transcript 2)

We must say to our students that learning English is something that needs responsibility that is one of our commitments. [sic] (Pre-service teacher's interview, Transcript 10)

To ensure the success of the English lessons, teachers must arrive to the classroom with a clear idea of what he or she will do, as well as take responsibility for the development of the class. Harmer (2015) stated that a good teaching plan will result in a better class time, which promotes more engaged behavior. A decisive, effective, and fair teacher enhances the success of the learning process. The following excerpt was retrieved from the tutor's journal,

It is necessary to prepare the lessons in advance because students expect to solve doubts then the planning of the activities based on Virtual-room updates lets preservice teachers to have a more engaged behaviour. [sic] (Tutor's journal)
There is an agreement to develop the tutoring support at the CAU with a specific structure, in a way that really suits the pre-service teachers' needs and responds to the demands from the B.A. program and the university.

\section{Empathetic attitude in English}

classes. The second category has to do with the affective factor that influences empathy in the classroom. Many initiatives have been carried out to understand the characteristics of an English teacher. For instance, Thompson (2007) applied questionnaires, portfolios, and observations to gather data. The findings showed that the participants valued teachers who were caring, creative, enthusiastic, patient, organized and respectful. Her study showed a preference for humanistic classrooms rather than teacher-centered ones. Teachers plan according to the joy, enthusiasm, empathy and acceptance toward students and their needs. The following excerpts come from the preservice teachers' interviews and highlight their perception of an English teacher as being empathetic toward his or her students.

\footnotetext{
More than a Licenciado we must be friends of our students, then we could be good leaders with responsibility and collaborators. [sic] (Pre-service teacher's interview, Transcript 10)
} 
All teachers need to be lovely with their students that's why being funny is the best way for having clever students. [sic] (Preservice teacher's interview, Transcript 8)

It is better to be friendly with our students, because we could have more than 30 students in the classroom and they want to learn, then try to be friends not enemies. [sic] (Pre-service teacher's interview, Transcript 7)

In this study, we highlight the teacher's role as being for students rather than against them. We should regard our students favorably and give them the benefit of the doubt when things go a bit wrong (Senior, 2008). One particular characteristic of Chiquinquirá's CAU is that students primarily come from rural areas. Because of this, tutors may feel more empathetic toward the students' needs. This is evident in the journal excerpt below.

Every Saturday students come to the Cau with lots of doubts, they expect an open attitude from us to listen to their questions and to guide them in the solution of their specific situations. Our attitude is to listen and to find the possible track is vital to show understanding of the complexity of studying in a distance program. [sic] (Tutor's Journal)

\section{Being open minded and} innovative. According to Dewey (1916, as cited by Meadows, 2012), openmindedness is a welcoming attitude, in which different points of view, suggestions, and information are welcomed with an active disposition. Based on this definition, teachers should listen to others' ideas. From the interviews, we found that the pre-service teachers considered that different points of view, other than their own voice, can enrich the teaching and learning process, as seen in the following excerpt from the questionnaire.

Being an innovator, because our students are expecting a lot from us, and be open minded to the learning and teaching process. [sic] (Pre-service teacher 1)

On the other hand, students also believe that teachers must be innovators, which means a teacher who tries new things or adapts existing things to new problems (Alvarado \& La Voy, 2006). The ability to innovate is evident in the following responses from the questionnaire:

An English teacher must be responsible, innovator and committed with the learning processes from the reflexive and honest role as a teacher. [sic] (Pre-service teacher 1)

Teaching innovation has to do with using multi-faceted and lively teaching methods, as well as content to stimulate students' interests in learning the material (Wu, 2002, as cited by Lee, 2011). Moreover, innovation implies a reflective process, in which the teacher identifies 
difficulties and looks for creative solutions, as expressed in the following excerpt.

During the second tutorial session, students were asked to reflect about the class. They said they enjoyed having dynamic and creative classes, because they feel excited when they don't know how the class will be carried out by the teacher. [sic] (Tutor's journal 1)

In essence, the pre-service teachers believed that a teacher should be innovative and open minded. He or she should have the ability to reflect on their teaching practice and break free from their comfort zone. Furthermore, a teacher should experiment and take risks in order to enrich their and their students' lives (Harmer, 2015).

\section{Being a knowledgeable teacher.}

Harmer (2015) stated that one of the main qualities of being a good teacher is to be knowledgeable about their subject (in this case the English language) and the craft of teaching. From the pre-service teachers' points of view, a knowledgeable teacher was one who could be used as a resource. He or she could guide students and provide accurate information on how to use the language when needed. In analyzing the participants' responses from the questionnaire, we found that the pre-service teachers consider that the role of the English teacher is to be experts in their field.
It is very important that English teachers know a lot about the language, I mean, be experts, if not, how we could teach something we don't know. [sic] (Preservice teacher 4)

According to Berlines (20016), an expert level teacher must have hundred of work hours of experience in addition to the ability to make appropriate pedagogical decisions. However, being an expert or "knowledgeable" teacher does not imply being a "know-it-all". Rather, an expert teacher should also have the capacity to help his or her students and understand their needs. Therefore, an expert teacher is also able to adapt their teaching practice to the context, as mentioned in the tutor's reflection below.

\footnotetext{
Along classes students ask me a lot of questions about the use of the language, even though, I have been teaching for more than 10 years, sometimes I don't have the answer. They have to understand that we are not google, we are learning every day about themselves and their lives. [sic] (Tutor's Journal 5)
}

Therefore, an expert teacher is someone who must know the different aspects of the language combined with a profound passion to understand the art of teaching. As Krishnamurti (n.d.) pointed out, an expert teacher invites discussion and encourages students to inquire and to think independently. 


\section{Conclusions}

Considering that listening to preservice teachers' voices can enrich the pedagogical practice, this study let the participants express their needs and views in order to empower them to be agents of change in distance education. In this sense, Salazar and Clbs (1979, as cited in Arias, 2016) mentioned that "social perception can be understood in three ways: the effects of context on the perception, people's perceptions and the perception about the environment" (p. 20). Therefore, preservices teachers are permeated by distance learning, their own life experiences, and their regional context.

To answer the research question, the main characteristics that the pre-service teachers perceived as being part of the English teacher's role were: being committed and engaged in the learning process, having an empathetic attitude, being innovative and open-minded, and being a knowledgeable teacher. The findings were meaningful because they came from the pre-service teachers' perceptions and voices based on their distance learning experiences. In addition, the pre-service teachers' perceptions of the role of the English teacher demonstrated an effect related to a positive atmosphere in the classroom and an active affective filter.
This study impacts the Bachelor program because it is an input to feed national research projects carried out at USTA, since they belong to the same macro project and subproject. All the initiatives that are currently developed at CAU Chiquinquirá aligned with narrative studies and support the mentorship program of the research division.

\section{About the Authors:}

Angélica María Carvajal has a B.A. in Education and Modern Languages with a Spanish and English focus. She holds an M.A. in Language Teaching and two specializations in English Teaching and Learning and Language Evaluation and Investigation. She has published several papers on inter-based project work, writing skills, mobile learning, and language practices.

Yolanda Duarte Medina has a B.A. in Philology and Languages with an emphasis in English. She holds a master's in Virtual Learning Environments. Her areas of interest include foreign language teaching, ICT tools, and virtual learning environments. She has also published articles related to mobile learning and preservice teacher education. 


\section{References}

Alvarado, F., \& La Voy, D. (2006).

Teachers: Powerful innovators. Generating classroom-based education reform. Academy for Educational Development, 4, 1-39.

Arias, C. C. (2006) Enfoques teóricos sobre la percepción que tienen las personas. Horizontes Pedagógicos, 8(1), 9-22.

Barkhuizen, G. (2014). Narrative research in language teaching and learning. Language Teaching, 47(4), 450466.doi:10.1017/S0261444814000 172

Berliner, D. (2004). Expert teachers: Their characteristics, development and accomplishments. Retrieved from https://www.researchgate.net/publi cation/255666969_Expert_Teacher s_Their_Characteristics_Developm ent_and_Accomplishments

Bonilla, M.I., Hernández, E., \& Medina, M. (2017). Macroprojects as a new didactic proposal for teaching EFL research in distance education. doi: 10.21125/iceri.2017.1944
Castañeda, J., \& Aguirre, A. (2018). Preservice English teachers' voices about the teaching practicum. How, 25 (1), 156-173.

Clandinin, D. J., \& Connelly, F. M. (2000). Narrative inquiry: Experience and story in qualitative research. San Francisco, CA: Jossey-Bass.

Clandinin, D. J., \& Huber, J. Narrative inquiry. In B. McGaw, E. Baker, \& P. P. Peterson (Eds.), International encyclopedia of education (3rd ed.). New York, NY: Elsevier.

Dörney, Z., \& Murphey, T. (2003). Group dynamics in the language classroom. Cambridge University Press.

Fajardo, J. A., \& Miranda, I. R. (2015). The paradox of the practicum: Affinity to and resistance towards teaching. Íkala, Revista de Lenguaje $y$ Cultura, 20 (3), 329-341.

Harmer, J. (2007) How to teach English.

NYC, NY: Pearson Education.

Harmer, J. (2015). The practice of English language teaching. Essex, England: Longman. 
Kiggundu, E., \& Nayimuli, S. (2009).

Teaching practice: A make or break phase for student teachers. South African Journal of Education, 29(3), 345-348.

Krishnamurti, J. (n.d.). Life ahead.

Retrieved from http://jiddukrishnamurti.net/en/lifeahead/1962-00-00-jiddukrishnamurti-life-aheadintroduction

Lauría de Gentile, P. (2009). Dealing with classroom management. The Teacher Trainer, 2-5.

Lee, Y. J. ( 2011 ). A case study on the effect of teaching innovation on learning effectiveness: Using a moderator of "integrating information technology into teaching". Journal of Human Resources \& Adult Learning, 7(1), 34-48.

Morales, Y. (2016). Unveiling pre-services teachers' attitudes toward teaching: The role of pedagogical practicums. PROFILE, 18(2), 47-61. doi.org/10.15446/profile.v18n2.49 591
Pavlenko, A., \& Norton, B. (2007). Imagined communities, identity, and English language learning. In A. Pavlenko \& A. Blackledge (Eds.), International handbook of English language teaching, pp. 669680. Springer US.

Pennington, M. (2010). Reflecting on teaching and learning: A developmental focus for the second language classroom. In J. Flowerdew, M. Brock, \& S. Hsia (Eds.), Perspectives on second language teacher education. Hong Kong: City Polytechnic

Polkinghorne, D. (1995). Narrative configuration in qualitative analysis. International Journal of Qualitative Studies in Education, 8(1), 5-21.

Rogers, J. (2013). What do (EFL) students say about good and bad teaching? Modern English Teacher, 22 (4), 70.

Senior, R. (2008) Developing rapport. English Teaching Professional, 54. 
Simonson, M. (2011). Distance education research: A review of the literature. J. Computing in Higher Education, 23 (2-3), 124-142. 10.1007/s12528011-9045

Trahar, S. (Ed.). (2011). Learning and teaching narrative inquiry: Travelling in the borderlands. Retrieved from https://ebookcentral.proquest.com

Thompson, S. (2007). How is a good teacher defined in a communicative, learner centred EFL classroom? (master's dissertation). Retrieved from www.birmingham.ac.uk/Document s/collegeartslaw/ceis/essays/mateft disssertations/Thompsondiss.pdf

Visser, L., Visser, Y. L., \& Amirault, R. (Eds.). (2014). Trends and issues in distance education ( $2^{\text {nd }} e d$.). International Perspectives. Retrieved from https://ebookcentral.proquest.com
Yan, C., \& He, C. (2010). Transforming the existing model of teaching practicum: A study of Chinese EFL student teachers' perceptions. Journal of Education for Teaching, $36(1)$, 57-73. doi:10.1080/02607470903462065

Zhang, Z., \& Kenny, R. (2010). Learning in an online distance education course: Experiences of three international students. The International Review of Research in Open and Distributed Learning, 11(1), 17-36. 